\title{
Effects of Combined Aerobic and Strength Training on Aerobic Capacity and Body Composition
}

\author{
Nuri Topsakal ${ }^{1}$, Osman Ates ${ }^{2}$, Burcak Keskin², Orhan Armutcu ${ }^{1}$ \\ ${ }^{1}$ Sports Sciences Faculty, Duzce University, Duzce, Turkey \\ ${ }^{2}$ Cerrahpasa Sports Sciences Faculty, Istanbul University, Istanbul, Turkey \\ Correspondence: Osman Ates, Cerrahpasa Sports Sciences Faculty, Istanbul University, Istanbul, Turkey.
}

Received: October 30, 2018

doi:10.11114/jets.v7i4.3997
Accepted: January 29, 2019 Online Published: February 14, 2019

URL: https://doi.org/10.11114/jets.v7i4.3997

\begin{abstract}
The purpose of this study was to analyse the effects of combined aerobic and strength training in circuit training on body fat ratio. The universe of this study was selected as 32 male participants who continue their training and do fitness for health. Participants were divided into 2 groups: aerobic group (16 people) and combined group (16 people). This study was applied for 8 weeks, 3 days per week, and 1 hour per day. Participants were informed about how the tests will be conducted. An aerobic capacity test, body fat percentage, body mass index, and waist-hip ratio were among the applied tests and measurements. Data were analysed with SPSS 21 package program. Average and standard deviation of obtained data were calculated. Results showed that results of aerobic and combined trainings were similarly, and both aerobic and combined training positively affected body weight, body mass index, body fat percentage, and aerobic capacity values. Additionally, it can be stated that aerobic exercises directly affected waist-hip ratio compared to combined exercises, and combined training was more efficient for waist-hip ratio.
\end{abstract}

Keywords: circuit, combined, aerobic, Bruce, fitness

\section{Introduction}

Immobility has increased the number of certain diseases that have existed for years but have been generally disregarded (posture problems, obesity, hypertension etc.). With development in science and technology, as people became dependent on the health sector due to diseases caused by physical immobility led the health sector to determine the main reason as immobility. Problems caused by immobility are not only personal problems but also social problems. It is believed that sports lead individuals to have more active lives and sustain quality life (Keleş, 2007). "Immobility is one of the most important general health problems of 21st century," (Blair, 2009).

Individuals who do not practice sports have higher chances of hypokinetic diseases linked with immobile lifestyle such as coronary heart disorder, hypertension, obesity, muscle-skeleton diseases (Özer, 2013). The easiest way to prevent these diseases is to be physically active (Zorba, 2011).

Physical exercise prevents hearth diseases, diabetes, high blood pressure, depression, anxiety, osteoporosis, certain types of cancers, and even premature deaths. Exercise increases physical activity capacity as well. Additionally, with exercise, individuals can struggle better against challenges in daily life. Although physical activity and performance accomplished by each individual varies at different levels, benefits of regular physical activity is the same (Fahey et al. 2005).

Today, the lifestyle, working hours, and environment of individuals can popularise immobility and lead to obesity and various diseases. An average of $15-20 \%$ of adult male body mass and an average of $25-30 \%$ of adult female body mass is fat (Akbulut et al., 2007).

The purpose of this study was to evaluate effects of combined strength and aerobic training on aerobic capacity and body composition.

\section{Material and Method}

\subsection{The Study Group}

The universe of this study consisted of gym members who continue their training and do fitness for health. The sample was 32 male participants randomly selected among gym members. After the tests, while aerobic training was applied to one 
group with 16 people $\left(21.5 \pm 2.80 \mathrm{yr}, 177 \pm 0.07 \mathrm{~cm}, 88.75 \pm 15.73 \mathrm{~kg}, 28.18 \pm 3.41 \mathrm{~kg} / \mathrm{m}^{-2}\right)$ and combined (aerobic-strength) training was applied to the other group with 16 people $\left(21.12 \pm 2.12 \mathrm{yr}, 175 \pm 0.04 \mathrm{~cm}, 86.06 \pm 10.88 \mathrm{~kg}, 27.92 \pm 3.00 \mathrm{~kg} / \mathrm{m}^{-2}\right)$. This study was applied for 8 weeks, 3 days per week, and 1 hour per day. The unit training program is given in Appendix 1 .

In pre- and post-tests, the Bruce protocol was applied for aerobic capacity. In Bruce protocol, the treadmill is started at $2.74 \mathrm{~km} / \mathrm{hr}(1.7 \mathrm{mph})$ and at a gradient (or incline) of $10 \%$. At three minute intervals the incline of the treadmill increases by $2 \%$, and the speed increases too. The test should be stopped when the subject cannot continue due to fatigue or pain, or due to many other medical indications (Strom et al., 2018).

Body fat percentage and body mass index was measured with bioelectric impedance - Tanita SC-330 method. Waist-hip ratio was measured with tape measure. Data were analysed with SPSS 21 package program. Average and standard deviation of obtained data were calculated.

All subjects gave their written, informed consent to participate after all procedures and risks were explained. This study was done in Istanbul/Turkey.

\subsection{Training Program}

Training content for participants that applied combined training was calculated as warm-up up on treadmill with 50\% pulse intensity, circuit movements in main stage, and aerobic exercises after this stage for 10 minutes and Karvonen formula with 10 minute stretching was given below.

\section{Circuit 1 Each move 20s x 3 set}

Dumbbell row

Dumbbell front raise

Stabilization

Medicine ball leg lift

Push-upSit-up cross

Circuit $1+5$ min walk

Circuit $2+5$ min elliptic

Circuit $1+5$ min cycling

Circuit $2+5$ min walk

Circuit $1+10$ min walk

Aerobic exercise group was completed as warm-up stage, and 10 minute walk at 50\% pulse intensity, 20 per movement at $60-70 \%$ pulse intensity in main stage, running, elliptic, and cycling calculated for Karvonen formula with 10 minutes stretching.

\subsection{Statistics}

Since data showed non-normal distribution, aerobic and combined training groups were compared with Mann-Whitney $\mathrm{U}$ test; pre- and post-tests were compared with Wilcoxon test; and differences were compared with Kruskal Wallis test. Statistical analysis were conducted with SPSS 21 package program. Significance level was accepted as $p<0.05$.

\section{Findings}

Data and statistical differenced obtained in this study were presented in table form.

Table 1. Descriptive statistic of aerobic and combined training groups

\begin{tabular}{|c|c|c|c|c|c|c|c|}
\hline Parameters & Groups & $\mathbf{N}$ & Min. & Max. & Ave. & Std. Dev. & $\mathbf{P}$ \\
\hline Age (year) & $\begin{array}{c}\text { Aerobic } \\
\text { Combined }\end{array}$ & $\begin{array}{l}16 \\
16\end{array}$ & $\begin{array}{l}18.00 \\
18.00\end{array}$ & $\begin{array}{l}26.00 \\
26.00\end{array}$ & $\begin{array}{l}21.50 \\
21.12\end{array}$ & $\begin{array}{l}2.80 \\
2.12\end{array}$ & .849 \\
\hline Height (m) & $\begin{array}{c}\text { Aerobic } \\
\text { Combined }\end{array}$ & $\begin{array}{l}16 \\
16\end{array}$ & $\begin{array}{l}1.62 \\
1.69\end{array}$ & $\begin{array}{l}1.96 \\
1.82\end{array}$ & $\begin{array}{l}1.77 \\
1.75\end{array}$ & $\begin{array}{l}0.07 \\
0.04\end{array}$ & .623 \\
\hline Body Mass (kg) & $\begin{array}{c}\text { Aerobic } \\
\text { Combined }\end{array}$ & $\begin{array}{l}16 \\
16\end{array}$ & $\begin{array}{l}73.00 \\
74.00\end{array}$ & $\begin{array}{l}142.00 \\
115.00\end{array}$ & $\begin{array}{l}88.75 \\
86.06\end{array}$ & $\begin{array}{l}15.73 \\
10.88\end{array}$ & .571 \\
\hline Body Mass Index (BMI) & $\begin{array}{c}\text { Aerobic } \\
\text { Combined }\end{array}$ & $\begin{array}{l}16 \\
16\end{array}$ & $\begin{array}{l}25.34 \\
24.42\end{array}$ & $\begin{array}{l}36.96 \\
37.55\end{array}$ & $\begin{array}{l}28.18 \\
27.92\end{array}$ & $\begin{array}{l}3.41 \\
3.00\end{array}$ & .678 \\
\hline Waist-Hip Ratio (cm) & $\begin{array}{c}\text { Aerobic } \\
\text { Combined }\end{array}$ & $\begin{array}{l}16 \\
16\end{array}$ & $\begin{array}{l}0.83 \\
0.80\end{array}$ & $\begin{array}{l}0.96 \\
0.91\end{array}$ & $\begin{array}{l}0.89 \\
0.86\end{array}$ & $\begin{array}{l}0.03 \\
0.02\end{array}$ & $.006 *$ \\
\hline Body Fat Percentage (\%) & $\begin{array}{c}\text { Aerobic } \\
\text { Combined }\end{array}$ & $\begin{array}{l}16 \\
16\end{array}$ & $\begin{array}{l}16.80 \\
15.10\end{array}$ & $\begin{array}{l}25.80 \\
24.80\end{array}$ & $\begin{array}{l}19.38 \\
18.57\end{array}$ & $\begin{array}{l}2.26 \\
2.22\end{array}$ & .220 \\
\hline
\end{tabular}

Difference in descriptive statistic of aerobic and combined training group was analysed as $p>0.01$. There was no significant difference between the two groups ( $p>0.05$ ). 
Table 2. Pre and post-test difference table for aerobic training group

\begin{tabular}{|c|c|c|c|c|c|c|c|}
\hline Parameters & Test & $\mathbf{N}$ & Min. & Max. & Ave. & Std. Dev. & $\mathbf{P}$ \\
\hline Body Mass (kg) & $\begin{array}{l}\text { Pre- } \\
\text { Post- }\end{array}$ & $\begin{array}{l}16 \\
16\end{array}$ & $\begin{array}{l}73 \\
69\end{array}$ & $\begin{array}{l}142 \\
135\end{array}$ & $\begin{array}{l}88.75 \\
84.68\end{array}$ & $\begin{array}{l}15.73 \\
14.60\end{array}$ & $.001 *$ \\
\hline Body Mass Index (BMI) & $\begin{array}{l}\text { Pre- } \\
\text { Post- }\end{array}$ & $\begin{array}{l}16 \\
16\end{array}$ & $\begin{array}{l}25.34 \\
24.11\end{array}$ & $\begin{array}{l}36.96 \\
35.14\end{array}$ & $\begin{array}{l}28.18 \\
26.88\end{array}$ & $\begin{array}{l}3.41 \\
3.01\end{array}$ & $.001 *$ \\
\hline Waist-Hip Ratio (cm) & $\begin{array}{l}\text { Pre- } \\
\text { Post- }\end{array}$ & $\begin{array}{l}16 \\
16\end{array}$ & $\begin{array}{l}0.83 \\
0.82\end{array}$ & $\begin{array}{l}0.96 \\
0.93\end{array}$ & $\begin{array}{l}0.89 \\
0.88\end{array}$ & $\begin{array}{l}0.03 \\
0.03\end{array}$ & $.001 *$ \\
\hline Body Fat Percentage (\%) & $\begin{array}{l}\text { Pre- } \\
\text { Post- }\end{array}$ & $\begin{array}{l}16 \\
16\end{array}$ & $\begin{array}{l}16.80 \\
15.10\end{array}$ & $\begin{array}{l}25.80 \\
24.80\end{array}$ & $\begin{array}{l}19.38 \\
17.70\end{array}$ & $\begin{array}{l}2.26 \\
1.56\end{array}$ & $.001 *$ \\
\hline $\mathrm{MaxVO}_{2}$ & $\begin{array}{l}\text { Pre- } \\
\text { Post- }\end{array}$ & $\begin{array}{l}16 \\
16\end{array}$ & $\begin{array}{l}28.11 \\
39.36\end{array}$ & $\begin{array}{l}65.47 \\
71.99\end{array}$ & $\begin{array}{l}46.05 \\
58.77\end{array}$ & $\begin{array}{c}11.47 \\
9.91\end{array}$ & $.001 *$ \\
\hline
\end{tabular}

There was a significant difference between pre- and post-test analysis of aerobic training group ( $\mathrm{p}<0.01)$.

Table 3. Pre and post-test difference table for combined training group

\begin{tabular}{cccccccc}
\hline Parameters & Test & N & Min. & Max. & Ave. & Std. Dev. & P \\
\hline Body Mass (kg) & Pre- & 16 & 74 & 115 & 86.06 & 10.88 & $\mathbf{. 0 0 1}^{*}$ \\
& Post- & 16 & 72 & 108 & 82.31 & 9.37 & \\
Body Mass Index (BMI) & Pre- & 16 & 24.42 & 37.55 & 27.92 & 3.00 & $\mathbf{. 0 0 1}^{*}$ \\
& Post- & 16 & 23.81 & 35.27 & 26.71 & 2.58 & \\
Waist-Hip Ratio (cm) & Pre- & 16 & 0.80 & 0.91 & 0.86 & 0.02 & $\mathbf{. 0 0 6}^{*}$ \\
& Post- & 16 & 0.81 & 0.89 & 0.85 & 0.02 & \\
Body Fat Percentage (\%) & Pre- & 16 & 15.10 & 24.80 & 18.57 & 2.22 & $\mathbf{. 0 0 1}^{*}$ \\
& Post- & 16 & 13.70 & 23.70 & 16.87 & 1.63 & \\
Max $^{*}$ & Pre- & 16 & 28.44 & 64.20 & 47.98 & 10.59 & $\mathbf{. 0 0 1} *$ \\
& Post- & 16 & 39.32 & 73.98 & 61.73 & 9.04 & \\
\hline
\end{tabular}

There was a significant difference between pre- and post-test analysis of combined training group $(\mathrm{p}<0.01)$.

Table 4. Pre-test difference table for aerobic and combined training groups

\begin{tabular}{|c|c|c|c|c|c|c|c|}
\hline Parameters & Group & $\mathbf{N}$ & Min. & Max. & Ave. & Std. Dev. & $\mathbf{P}$ \\
\hline Body Mass (kg) & $\begin{array}{c}\text { Aerobic } \\
\text { Combined }\end{array}$ & $\begin{array}{l}16 \\
16\end{array}$ & $\begin{array}{l}73 \\
74\end{array}$ & $\begin{array}{l}142 \\
115\end{array}$ & $\begin{array}{l}88.75 \\
86.06\end{array}$ & $\begin{array}{l}15.73 \\
10.88\end{array}$ & .571 \\
\hline Body Mass Index (BMI) & $\begin{array}{l}\text { Aerobic } \\
\text { Combined }\end{array}$ & $\begin{array}{l}16 \\
16\end{array}$ & $\begin{array}{l}25.34 \\
24.42\end{array}$ & $\begin{array}{l}36.96 \\
37.55\end{array}$ & $\begin{array}{l}28.18 \\
27.92\end{array}$ & $\begin{array}{l}3.41 \\
3.00\end{array}$ & .678 \\
\hline Waist-Hip Ratio (cm) & $\begin{array}{c}\text { Aerobic } \\
\text { Combined }\end{array}$ & $\begin{array}{l}16 \\
16\end{array}$ & $\begin{array}{l}0.83 \\
0.80\end{array}$ & $\begin{array}{l}0.96 \\
0.91\end{array}$ & $\begin{array}{l}0.89 \\
0.86\end{array}$ & $\begin{array}{l}0.03 \\
0.02\end{array}$ & .06 \\
\hline Body Fat Percentage (\%) & $\begin{array}{l}\text { Aerobic } \\
\text { Combined }\end{array}$ & $\begin{array}{l}16 \\
16\end{array}$ & $\begin{array}{l}16.80 \\
15.10\end{array}$ & $\begin{array}{l}25.80 \\
24.80\end{array}$ & $\begin{array}{l}19.38 \\
18.57\end{array}$ & $\begin{array}{l}2.26 \\
2.22\end{array}$ & .220 \\
\hline $\mathrm{MaxVO}_{2}$ & $\begin{array}{c}\text { Aerobic } \\
\text { Combined }\end{array}$ & $\begin{array}{l}16 \\
16\end{array}$ & $\begin{array}{l}28.11 \\
28.44\end{array}$ & $\begin{array}{l}65.47 \\
64.20\end{array}$ & $\begin{array}{l}46.05 \\
47.98\end{array}$ & $\begin{array}{l}11.47 \\
10.59\end{array}$ & .678 \\
\hline
\end{tabular}

There was no significant difference for pre-test analysis of aerobic and combined training groups $(\mathrm{p}>0.05)$.

Table 5. Post-test difference table for aerobic and combined training groups

\begin{tabular}{|c|c|c|c|c|c|c|c|}
\hline Parameters & Group & $\mathbf{N}$ & Min. & Max. & Ave. & Std. Dev. & $\mathbf{P}$ \\
\hline Body Mass (kg) & $\begin{array}{c}\text { Aerobic } \\
\text { Combined }\end{array}$ & $\begin{array}{l}16 \\
16\end{array}$ & $\begin{array}{l}69 \\
72\end{array}$ & $\begin{array}{l}135 \\
108\end{array}$ & $\begin{array}{l}84.68 \\
82.31\end{array}$ & $\begin{array}{c}14.66 \\
9.37\end{array}$ & .558 \\
\hline Body Mass Index (BMI) & $\begin{array}{c}\text { Aerobic } \\
\text { Combined }\end{array}$ & $\begin{array}{l}16 \\
16\end{array}$ & $\begin{array}{l}24.11 \\
23.81\end{array}$ & $\begin{array}{l}35.14 \\
35.27\end{array}$ & $\begin{array}{l}26.88 \\
26.71\end{array}$ & $\begin{array}{l}3.01 \\
2.58\end{array}$ & .692 \\
\hline Waist-Hip Ratio (cm) & $\begin{array}{l}\text { Aerobic } \\
\text { Combined }\end{array}$ & $\begin{array}{l}16 \\
16\end{array}$ & $\begin{array}{l}0.82 \\
0.81\end{array}$ & $\begin{array}{l}0.93 \\
0.89\end{array}$ & $\begin{array}{l}0.88 \\
0.85\end{array}$ & $\begin{array}{l}0.03 \\
0.02\end{array}$ & .06 \\
\hline Body Fat Percentage (\%) & $\begin{array}{l}\text { Aerobic } \\
\text { Combined }\end{array}$ & $\begin{array}{l}16 \\
16\end{array}$ & $\begin{array}{l}15.30 \\
13.70\end{array}$ & $\begin{array}{l}21.40 \\
20.70\end{array}$ & $\begin{array}{l}17.70 \\
16.87\end{array}$ & $\begin{array}{l}1.56 \\
1.63\end{array}$ & .141 \\
\hline $\mathrm{MaxVO}_{2}$ & $\begin{array}{l}\text { Aerobic } \\
\text { Combined }\end{array}$ & $\begin{array}{l}16 \\
16\end{array}$ & $\begin{array}{l}39.36 \\
39.32\end{array}$ & $\begin{array}{l}71.99 \\
73.98\end{array}$ & $\begin{array}{l}58.77 \\
61.73\end{array}$ & $\begin{array}{l}9.91 \\
9.04\end{array}$ & .346 \\
\hline
\end{tabular}

There was no significant difference for post-test analysis of aerobic and combined training groups $(p>0.05)$. 
Table 6. Analysing differences between aerobic and combined training groups

\begin{tabular}{cccccccc}
\hline Parameter Difference & Group & N & Min. & Max. & Ave. & Std. Dev. & P \\
\hline Body Mass & Aerobic & 16 & 1.00 & 7.00 & 4.06 & 1.61 & .396 \\
Difference & Combined & 16 & 2.00 & 7.00 & 3.75 & 1.69 & \\
Body Mass Index & Aerobic & 16 & 0.32 & 2.28 & 1.29 & 0.52 & .497 \\
Difference & Combined & 16 & 0.61 & 2.28 & 1.20 & 0.51 & \\
Waist-Hip Ratio & Aerobic & 16 & 0.01 & 0.04 & 0.01 & 0.01 & .613 \\
Difference & Combined & 16 & -0.01 & 0.04 & 0.01 & 0.01 & \\
Body Fat Percentage & Aerobic & 16 & 0.70 & 4.40 & 1.67 & 0.88 & .593 \\
Difference & Combined & 16 & 0.90 & 4.10 & 1.70 & 0.74 & \\
MaxVO $_{2}$ & Aerobic & 16 & 6.53 & 22.62 & 12.72 & 4.28 & .376 \\
Difference & Combined & 16 & 8.77 & 19.25 & 13.74 & 3.08 & \\
\hline
\end{tabular}

There was no significant difference for difference analysis of aerobic and combined training groups ( $p>0.05)$.

\section{Discussion and Conclusion}

In this study, the effects of combined exercise training model on aerobic capacity and body composition was analysed. Statistics showed that there was a significant difference for body fat percentage, however, there was no significant difference for aerobic capacity. However, numerical development was observed.

There was a statistically significant difference in body fat percentage in both training models. However, in numerical terms, development of combined training group was at higher level than aerobic training group. Although there were differences between groups, there was no statistically significant difference.

In this study, the average age of Aerobic Training group was $21.50 \pm 2.80$, height average was $1.77 \pm 0.07$, body mass average was $88.75 \pm 15.73$, body mass index average was $28.18 \pm 3.41$, waist-hip ratio was $0.89 \pm 0.03$, and body fat percentage was $19.38 \pm 2.26$. The average age of Combined Training group was $21.12 \pm 2.12$, height average was $1.75 \pm$ 0.04 , body mass average was $86.06 \pm 10.88$, body mass index average was $27.92 \pm 3.00$, waist-hip ratio was $0.86 \pm 0.02$, and body fat percentage was $18.57 \pm 2.22$. Difference in descriptive statistic of aerobic and combined training group was analysed as $p>0.05$. There was no significant difference between two groups ( $p>0.05)$.

Other studies that are similar to this study found that recent combined trainings (aerobic training and strength training) caused a decrease in fat levels around abdominal area and combine trainings were more effective than food intake limitations (Park et al., 2003), and using combined aerobic and strength exercise was the most effective training program in obesity training (Hill et al., 1987; Keles, 2007).

In this study, there was a significant difference between pre- and post-test analysis of aerobic training group ( $\mathrm{p}<0.01)$. In this study, there was a significant difference between pre- and post-test analysis of combined training group ( $\mathrm{p}<0.01)$.

Another study analysed the effect of a 12-week aerobic and combined exercise training on middle aged male and female participants. A total of 75 sedentary individuals participated in this study voluntarily. 46 of these participants were male (age: $33.8 \pm 6.6$ years, BMI: $27.9 \pm 12.8 \mathrm{~kg} / \mathrm{m} 2$ ) and 29 were female (age: $34.7 \pm 4.5$ years, BMI: $26.8 \pm 2.9 \mathrm{~kg} / \mathrm{m} 2$ ). Aerobic training intensity was calculated with Karvonen formula and determined as $60-70 \%$. Strength exercise was applied 2 set and 12 repetition. Accordingly, applied exercise has positive contribution to body composition by significantly decreasing body mass, body mass index, body fat ratio, fat-free muscle mass, waist measurement, hip measurement, waist-hip ratio.

Results of this study had different results for body mass, body mass index, body fat ratio and similar results for waist measurement, hip measurement, and waist-hip ratio values. As stated earlier, difference in study groups may lead to different results. As the study group was middle aged individuals, this may lead to different results. Additionally, training duration may also cause these differences (Kafkas et al., 2009).

According to results that has similar training protocol in this study, Nindl et al. applied 6 month combined training program for 5 days a week on 31 healthy female and found that there was $2.2 \%$ difference in body mass index (Nindl, Harman, and Marx, 2000).

In this study, there was significant difference between pre- and post-test analysis of combined training group ( $\mathrm{p}<0.01)$.

Other studies that show no similarities and have opposite findings are as follows: Drummond et al. (2005) analysed combined effect of strength and aerobic training and compared effects of these two method when applied on different times. Researchers stated that order of strength and aerobic training affected post-training over oxygen consumption. It was found that post-training over oxygen consumption was larger when aerobic training (cardio) was done before strength and resistance and cardio was physiological harder after weight training. Authors suggested that if a combined 
training will be planned with these two methods, aerobic training should be done before weight training (Drummond et al. 2005).

Other studies that investigated which combined training method (aerobic and strength training) was effective on better fat burning process showed that aerobic training increased energy consumption with lipolysis activation (Poehlman and Horton, 1989; Keleş, 2007). Additionally, it was observed that aerobic training was more effective for decreasing body fat and body mass while strength training was more effective to increase fat-free body mass or preserved existing body mass (Ballor et al. 1988; Keles, 2007). Also, some studies showed that fat-free body mass increased with weight training and aerobic training decreased body fat (Eric et al., 2000).

There are high number of national and international studies in the literature and results of these studies are similar. These studies showed that to achieve positive effects, training should be medium or long term. Short-term training i.e.. training less than 12 weeks period has no effect on decreasing body mass (Kraemer et al. 2002).

More studies are needed to exactly determine effect of strength exercise on preventing weight gain. Although strength training is regarded as an effective tool to lose wright, it is also known that this training decreases various chronical disease risk factors, decrease fat mass, increase fat-free body mass, and related with health (Donelly et al., 2009).

Results showed that physical parameter results of aerobic and combined trainings conducted for 8-week long training protocol were similarly, and both aerobic and combined training positively affected body weight, body mass index, body fat percentage, and $\max \mathrm{VO}_{2}$ values. Additionally, it can be stated that aerobic exercises directly affected waist-hip ratio compared to combined exercises, and combined training was more efficient for waist-hip ratio.

\section{Following recommendations can be made based on the results of this study:}

- To see more clear effects of training application, this application may be longer than 8 weeks.

- Future researchers may add strength training in a separate group that was added in combined training and this way, separate effects of strength training may be compared with other trainings.

- In addition to waist and hip measurements, arm and leg groups can be included in measurements.

- A similar study may be applied with diet program and show positive results.

- A similar study may include laboratory measurements and different physiological parameters may be considered.

\section{References}

Akbulut, G., Ozmen, M., \& Besler, T., (2007). Age of obesity. Science and Technology, 25, 72-79.

Altunsoy, K. (2014). Investigating effects of aerobic exercise and combined exercise programmes on body composition and resting metabolic rate, Master Thesis, Abant Izzet Baysal University, Health Sciences Institute, Trainer Training Department, Bolu.

American College of Sports Medicine, ACSM' Guideline for Exercise Testing and Prescription. (2010). Philadelphia: Wolters Kluwer/Lippincott Williams\&Wilkins; 3 Edition: p.1-22.

American Council on Exercise (ACE). (1997). Personal Trainer Manuel 'The Resource for Fitness Professionals'. 2. Edition.

Blair, S. N. (2009). Physical inactivity: the biggest public health problem of the 21st Century. Br J Sports Medicane, $43(1), 1-2$.

Donelly, J. E., Blair, S. N., Jakicic, J. M., Manore, M. M., Rankin, J. W., \& Smith, B. K. (2009). Appropriate physical activity intervention strategies for weight loss and prevention of weight regain for adults. American College of Sports Medicine, 4l(2), 459-471. https://doi.org/10.1249/MSS.0b013e3181949333

Drummond, M. J., Vehrs, P. R., Schaalje, G. B., \& Parcell, A. C. (2005). Aerobic and resistance exercise sequence affects excess post exercise oxygen consumption. J Strength Cond Res., 19(2), 332-337.

Duman, P. O. (2016). The effect of eight-station circular training programme on the results of bourdon attention test of 10-12 age children, Master Thesis, Cag University, Social Sciences Institute, Department of Psychology, Mersin.

Ergun, A., \& Erten, S. F. (2004). Body Mass Index and Waist Circumference in estimation of Obesity in Students, Ankara University Medical Faculty Journal, 57(2).

Fahey, T. D., Insel, P. M., \& Roth, W. T., (2005). FIT and WELL 'CoreConcepts and Labs In Physical Fitness and Wellness. Mc Graw Hill. Sixth Edition.

Frontera, W., Silver, J., \& Rizzo, T. (2014). Essentials of Physical Medicine and Rehabilitation, eBook 
ISBN: $9780323222723,:$ p. 1619-1622.

Gunay, M., Cicioglu, G., \& Kara, E. (2006). Metabolic and Heat Adaptation to Exercise. Gazi Publications, Ankara.

Hoeger (2010). WWK HS. Lifetime Physical Fitness and Wellness: A Personalized Program. 11th ed: Cengage Learning: p.1-30.

Hoeger, W. W. K., \& Hoeger, S. A. (2004). Principles and Labs For Physical Fitness and Wellness, Seventh Edition.

ISAK, (2001). The International Society for the Advancement of Kinanthropometry. First printed

Kafkas, M. E., Açak, M., \& Karademir, T. (2009). The Effects Of 12-Week Regular Aerobic And Resıstance Exercıses On The Body Composition Of Middle-Aged Men And Women, Nigde University Journal of Physical Education and Sport Sciences, 3(3).

Kamar, A. (2008). Skill and Talent Performance Tests in Sport, Nobel Publishing Ankara 2nd Edition.

Keles, A. (2007). The effects of the priority in the aerobic training and strength training combination for burning fat in a workout, Master, Institute of Educational Sciences, The University of Marmara, The College of Physical Education and Sport, Istanbul.

Kraemer, R. R., Chu, H., \& Castracane, V. D. (2002). Leptin and Exercise. Exp Biol Med; 227, $701-708$. https://doi.org/10.1177/153537020222700903

Nieman, D. C. (2011). Physical Fitness and Health Defined, Exercise Testing And Prescription: A Health Related Approach. 7th ed. New York: The McGraw-Hill Companies; 2011: p.3-16.

Nindl, B., Harman, E. A., Marx, J. O., Gotshalk, L. A., Frykman, P. F., Lammi, E., ... Kraemer, W. J. (2000). Regional body composition Changes in women after 6 months of periodized physical training, Journal of Applied Physiology, 88(6), 2251-2259. https://doi.org/10.1152/jappl.2000.88.6.2251

Ozer, K. (2013). Physical fitness. 4th Edition, Ankara, Nobel Academic.

Park, S. K., Park, J. H., Kwon, Y. C., Kim, H. S., Yoon, M. S., \& Park, H. T. (2003). The effect of Combined Aerobic and Resistance Exercise Training on Abdominal Fat in Obese Middle-Aged Women. J Physiol Anthropol Appl Human Sci., 22(3), 129-135. https://doi.org/10.2114/jpa.22.129

Pekcan, G. (2008). Determination of Nutritional Status. 1st Edition, Ankara, Klasmat Matbaacilik, Ankara.

Peterson, V. (1998). Dieting Behaviours and Body Image: A Study of Gymnasts and Netball Players. Unpublished Honours Thesis. University of Newcastle.

Poehlman, E. T., Dvorak, R. V., Denino, W. F., Brochu, M., \& Ades, P. A. (2000). Effects of resistance training and endurance training on insulin sensitivity in nonobese, young women: a controlled randomized trial. The Journal of Clinical Endocrinology \& Metabolism, 85(7), 2463-2468. https://doi.org/10.1210/jc.85.7.2463

Scholich, M. (1999). Circuit Training for All Sports. Methodology of Effective Fitness Training. Toronto. Canada:Sports Book Publisher

Sonmez, G. T. (2002). Exercise and Sport Physiology, Ata Ofset Publisher, Bolu.

Strom, C. J., Pettitt, R. W., Krynski, L. M., Jamnick, N. A., Hein, C. J., \& Pettitt, C. D. (2018). Validity of a customized submaximal treadmill protocol for determining $\mathrm{VO}_{2 \max }$ European Journal of Applied Physiology, 118(9), 17811787. https://doi.org/10.1007/s00421-018-3908-X

Zorba, E. (2011). Lifetime Sport. Bedray Press Publishing,1st Edition, Istanbul.

\section{Copyrights}

Copyright for this article is retained by the author(s), with first publication rights granted to the journal.

This is an open-access article distributed under the terms and conditions of the Creative Commons Attribution license which permits unrestricted use, distribution, and reproduction in any medium, provided the original work is properly cited. 